\title{
Managerial optimism and corporate investment: Some empirical evidence from Taiwan
}

\author{
Yueh-hsiang $\operatorname{Lin}^{\mathrm{a}, *}$, Shing-yang $\mathrm{Hu}^{\mathrm{b}}$, Ming-shen Chen ${ }^{\mathrm{b}}$ \\ a Department of Finance, Takming College, Taipei, Taiwan \\ ${ }^{\mathrm{b}}$ Department of Finance, National Taiwan University, Taipei, Taiwan \\ Received 27 February 2004; accepted 23 December 2004 \\ Available online 20 July 2005
}

\begin{abstract}
In this paper we examine the relation between managerial optimism and corporate investment decisions. Analyzing a sample of listed companies in Taiwan, we propose a measure of managerial optimism from management earnings forecasts, and find that in more financing constrained firms, optimistic managers exhibit higher investment-cash flow sensitivity than do non-optimistic managers.
\end{abstract}

(C) 2005 Elsevier B.V. All rights reserved.

JEL classification: G31; G32

Keywords: Managerial optimism; Investment; Financing constraints

\section{Introduction}

This paper aims to examine the impact of managerial irrationality on corporate policies. We focus on the role of managerial optimism in explaining a firm's investing decisions. Optimism here is a personal characteristic, which describes a manager's systematic overestimation of a firm's future performance.

\footnotetext{
* Corresponding author. No. 56, Sec. 1, Huanshan Rd., Neihu District, Taipei City, Taiwan 11451, ROC. Tel.: +8862 26585801x2771; fax: +886226582507.

E-mail address: d90723013@ntu.edu.tw (Y. Lin). 
The cognitive psychology literature suggests that most people naturally display optimistic expectations about the future. Managers are particularly prone to exhibit optimism in their decision-making for numerous explanations. First, individuals in general are more optimistic when they believe that outcomes are under their control (e.g., Weinstein, 1980), and managers in particular are more optimistic whey they have a great deal of control over their firms' performance (e.g., March and Sharpia, 1987). Second, individuals are more optimistic about outcomes when they are highly committed (e.g., Weinstein, 1980), and managers are committed to the firms' good performance because their personal wealth, reputation, and employability are highly dependent on it (e.g., Gilson, 1989). Third, people tend to overstate their skills relative to the average of others when the reference point is abstract (e.g., Larwood and Whittaker, 1977; Alicke et al., 1995). A manager who seeks external financing for investment purposes is prone to overstate the value and importance of the project relative to the average portfolio of the projects introduced by other managers to the market (e.g., Malmendier and Tate, 2005). The explanations provide foundations of the subject, the impact of managerial optimism on corporate decisions, in behavioral finance. ${ }^{1}$

In his well-known paper on this subject, Roll (1986) argues that managerial optimism (i.e. hubris) results in "winner's curse" when it comes to corporate takeovers. Recently, there has been a growing amount of research into the impact of managerial optimism on various corporate decisions. DeAngelo et al. (1996) show that managerial optimism may cause a firm's dividend to go up. Hackbarth (2002) proposes that optimistic managers will choose higher leverage and follow a pecking order. Gervais et al. (2002) further prove that when optimism induces managers to a higher level of effort, it may be less expensive for shareholders than hiring only moderately optimistic managers.

As for the investment decisions specifically, Heaton (2002) shows that the existence of managerial optimism may result in a distorted investment policy, in forms of either underinvestment or overinvestment, without invoking the traditional theories of agency and information asymmetry. Due to the systematic overvaluation of the projects, optimistic managers may invest in negative NPV projects with sufficient internal funds. Once internal funds are exhausted and firms are constrained, because of overestimating the probability of good firm performance versus the capital market's outlook, optimistic managers have the tendency to perceive the market as undervaluing their own firm. They will be reluctant to issue new equity, and then reject positive NPV projects. The twist here is that managerial optimism could increase the sensitivity between corporate investment and cash flow in constrained firms. This is so because optimistic managers will invest more than non-optimistic managers do when the cash flows are ample, and less when the cash flows are insufficient.

Even the empirical prediction is clear; however, empirical evidence for the hypothesis is relatively rare due to a lack of the proxy for managerial optimism.

\footnotetext{
${ }^{1}$ For a brief introduction to the research of behavior finance, see Ritter (2003) on this journal.
} 
Using the Chief Executive Officer's (CEO's) personal portfolio of the firm's options and stockholdings of American companies, Malmendier and Tate (2005) construct measures of managerial overconfidence and find that in American companies, managerial overconfidence affects the investment-cash flow sensitivity. ${ }^{2}$ Given the importance of this subject, we believe that additional tests are warranted. To provide a robustness check of Heaton (2002) model, we use listed companies in Taiwan as the sample. To the best of our knowledge, this paper is the first empirical study outside of the United States on the relation between managerial optimism and corporate investment decisions.

Another contribution of this paper is to provide an alternative measure of optimism using management earnings forecasts. If CEOs are optimistic in the assessment of future outcomes, they are more likely to provide a forecast that is biased upward. An important merit of management earnings forecasts is their prevalence because in most countries, earnings forecasts are allowed and legislatively regulated. The measure constructed from earnings forecasts could be similarly established in these countries.

We classify each CEO in our sample as optimistic if the number of the CEO's upwardly-biased forecasts is more than that of the downwardly-biased. However, an obstacle of the classification is that CEOs may have reasons other than optimism to deliberately bias their forecasts. To address this concern, we exclude all those forecasts that may be contaminated by incentive effects in constructing the measure. For example, intending to make a stock offering, some firms may temporarily boost their stock price by releasing upwardly-biased forecasts. (e.g., Chin et al., 1999; Lang and Lundholm, 2000). Therefore, if a firm conducts any stock offerings within 12 months after the forecasts, we regard these forecasts as tainted by the CEOs' incentives and remove them from the sample.

To ensure that whether a firm is constrained is properly identified, we follow the literature of "financing constraints" to use several classifications of firms. Controlling the effect of the traditional agency or information asymmetry problems, we find that managerial optimism increases investment-cash flow sensitivity for constrained companies under the different sample splits. This finding is consistent with Heaton (2002) prediction. To substantiate our use of earnings forecasts as a measure of optimism, we also measure optimism with the CEOs' stockholdings as in Malmendier and Tate (2005). We find that the measure constructed from stockholdings provide similar results in our sample.

The rest of this paper is organized as follows. Section 2 describes the empirical methodology and the sample. The empirical results are presented in Section 3. In Section 4 , we conclude with a summary.

\footnotetext{
${ }^{2}$ According to psychology literature, managerial upward bias towards future firm performance may be due to overconfidence, resulting from an overestimation of one's own abilities (such as managerial skills); or optimism, originating in an overestimation of exogenous outcomes (such as the growth of the economy) relating to the probability of success. Melmendier and Tate (2005) label their measure as "overconfidence;" however, the rationale of Heaton (2002) model depends only on whether managers indeed possess an upward bias towards future firm performance, whether this bias is a result of their optimism or overconfidence. Therefore, we do not discriminate between overconfidence and optimism hereinafter in this paper.
} 


\section{Methodology and sample}

\subsection{Hypothesis}

In Heaton (2002) model, optimistic managers will overvalue both their investment projects and firms. The overvaluation of the projects causes optimistic managers invest more than non-optimistic managers do with sufficient internal funds. Once internal funds are exhausted and firms are constrained, optimistic managers overestimate the probability of good firm performance versus the capital market's outlook and perceive the market as undervaluing their own firm. Therefore, they will be reluctant to issue new equity, and then invest less than non-optimistic managers do. Thus, the hypothesis for the impact of managerial optimism on the investment-cash flow sensitivity is:

Hypothesis. In constrained firms, the investment-cash flow sensitivity is larger for optimistic managers than non-optimistic managers.

To test this hypothesis, we use a constrained subsample to run the following empirical model:

$$
I_{i t}=\beta_{1}+\beta_{2} C_{i t}+\beta_{3} Q_{i t-1}+\beta_{4} O_{i}+\beta_{5} C_{i t} Q_{i t-1}+\beta_{6} C_{i t} O_{i}+\varepsilon_{i t},
$$

where $I$ is the investment, $C$ is the cash flow from operation, $Q$ is the ratio of market value to book value of equity, and $O$ is the dummy variable (i.e. the optimism measure) which is 1 if the manager is classified optimistic and 0 if he/she is not. To avoid possible distortion caused by firm size discrepancy, we normalize the investment and the cash flow by total assets at the beginning of the fiscal year. The hypothesis predicts that $\beta_{6}$, the coefficient on the interaction of cash flow and the optimism dummy variable, is positive.

Given that our sample pools cross-sectional with time-series data, investment can also be affected by macro factors not contained in our empirical model. Therefore, aside from OLS regressions, we also include in the regressions the fixed and the random effects to model the yearly effect and obtain similar results. We only present the results of OLS regressions in Section 3 so as to save space. ${ }^{3}$

Another important issue to test the hypothesis is the identification of the extent of firms' financing constraints. We follow the literature of "financing constraints" and use several classifications to split our sample firms into two groups: one is more constrained and the other less constrained.

The dividend payout is the first classification, spawned by Fazzari et al. (1988) and extensively used by other following literature (e.g., Hubbard et al., 1995; Calomiris and Hubbard, 1995; Agung, 2000). Fazzari et al. (1988) argue that dividend payments are useful for identifying firms suffering from financing constraints. If the external financing for a firm is costly, the firm should retain its cash and pay low cash dividends out. For each firm, we calculate the ratio of the number of years with non-zero cash dividend to that in our sample period. Then we rank all firms from small to large by the ratios and define the smaller 50\% firms as more constrained and the larger 50\% firms as less constrained.

\footnotetext{
${ }^{3}$ All the results not reported in this paper are available from the authors.
} 
The second classification here is interest coverage. Literature (e.g., Whited, 1992; Hu and Schiantarelli, 1998; Cleary, 1999) uses the extent to which the interest covered by the firms' earnings as a proxy for the firm's financing ability. Firms with high interest expenses relative to earnings are likely to have limited access to debt market and face the borrowing constraints. For each firm we calculate its average interest coverage, the ratio of interest expense to the sum of the interest expense and the cash flow, in our sample period. Then we rank the firms from large to small by the averages and define the larger $50 \%$ firms as more constrained and the smaller $50 \%$ firms as less constrained.

Some literature identifies financing constraints by firm characteristics which are tied to problems of agency or asymmetric information. ${ }^{4}$ Agency or information asymmetry problems between insiders and outside investors result in a gap between the cost of external financing and internal financing. As a consequence, firms with larger agency or information asymmetry problems may likely to face the gap and financing constraints.

Among the characteristics, we use firm size and age, respectively, to be our third and fourth classifications. Large, mature firms are less likely to involve a problem of information asymmetry since outside investors will tend to know more about firms that have been covered by more analysts and visible for an extended period of time. For each firm we calculate its average total assets at the beginning of the fiscal year in our sample period. Then we rank the firms from small to large by the averages and define the smaller $50 \%$ firms as more constrained and the larger 50\% firms as less constrained. We use the firms' listed dates to compute their ages. By ranking the firms from young to old, we define the younger $50 \%$ firms as more constrained and the older 50\% firms as less constrained.

The fifth classification is business group affiliation. Hoshi et al. (1991) suggest that firms in business groups may have lower information asymmetry problems. The scope of the business group allows the groups to internally replicate the financing functions provided or capital markets. We collect the information of business groups from the Business Groups in Taiwan (1990-2002) and define firms in groups as less constrained and others are more constrained.

Schaller (1993) argues that manufacturing firms rely largely on specialized assets for which resale markets are often thin. Thus, manufacturing firms may have a larger financing cost than do non-manufacturing firms. Our sixth classification is that whether the firms are manufacturing firms. We follow Shen and Wang (2000) to define firms in construction, tourism, transportation, or department-store industry as non-manufacturing (and less constrained) and others as manufacturing (and more constrained) firms.

The seventh classification used here is ownership concentration. The more concentrated ownership of the firm, the more closely insiders' interests should coincide with those of outside investors, and thus the firms are less likely to involve a problem of agency cost (Hubbard, 1998). ${ }^{5}$ For each firm we calculate its average monthly shareholding rate of

\footnotetext{
${ }^{4}$ See a related review by Hubbard (1998).

5 Another explanation of this classification is from the problem of asymmetry information (e.g., Schaller; 1993). Here we focus, however, is whether managerial optimism makes a contribution to investment-cash flow sensitivity in firms with less concentrated ownership. The main result of this paper is not impacted by the explanation here.
} 
director in our sample period, rank the firms from small to large by the averages, and then define the smaller 50\% firms as more constrained and the larger 50\% firms as less constrained.

Our last classification, cash flow rights of controlling shareholder, is borrowed from literature of corporate governance and tied to the agency problems. With large cash flow rights, controlling shareholders have less incentive to expropriate outside investors. Therefore, the more cash flow rights the controlling shareholders have, the firms are less likely to involve a problem of agency cost (e.g., La Porta et al., 1999). Using the information of large business groups from the Business Groups in Taiwan (1990-2002), we follow the approach of La Porta et al. (1999) to compute the average yearly cash flow rights of the ultimate controlling shareholders in our sample firms. We rank the firms from small to large by the averages, and then define the smaller $50 \%$ firms as more constrained and the larger $50 \%$ firms as less constrained.

\subsection{Sample}

Our sample consists of the companies listing on the Taiwan Stock Exchange (TSE) and the Over the Counter (OTC) during the period from 1985 to 2002. Except the business groups' information, collected from the Business Groups in Taiwan (1990 2002), other data employed in this paper are from Taiwan Economic Journal database (TEJ). Firms in the financial industries or with fiscal years ending in months other than December are excluded. To avoid survivorship bias (e.g., Kothari et al. (1995)), we remove data before the firms' Initial Public Offering (IPO) and include all delisted firms.

The context of our measures involves management forecasts for earnings before tax. The earnings forecasts data contain both mandatory forecasts from 1991 and voluntary forecasts from 1985. The mandatory forecasts are required by the regulatory agency, Securities and Futures Commission (SFC) and the voluntary forecasts are disclosed by firms through the media. ${ }^{6}$ Contrary to most literature, which studies voluntary forecasts or mandatory forecasts only, we retain both mandatory forecasts and voluntary forecasts in our sample since optimistic managers should have overestimations of earnings; whether they are required or voluntary to publish forecasts. To ensure that our results are not driven by this choice, we also use only voluntary forecasts or only mandatory forecasts to construct our optimism measures and find similar results. To save space, we only present the results based on both forecasts in Section 3. Some of the voluntary forecasts in the sample are in fact estimated by the media reporter through the interview. We drop these observations. We also eliminate the forecasts that are not released within the same fiscal year.

The forecasts do not record the publisher; however, optimism is a personal characteristic. Although the forecasts may be the consensus of the whole management

\footnotetext{
${ }^{6}$ Legislation covering the quantitative forecasts of statement was firstly established in 1991 by the regulation "Criteria Governing the Offering and Issuance of Securities by Securities Issuers," which requires a company to publicize a prospectus to contain an estimate of profits for reasons such as IPO or SEO, merge or acquisition, and the acquisition or the disposition of main assets. Some British Commonwealth countries, like Singapore, Canada, Malaysia and the UK, also have similar regulations for mandatory forecasts.
} 
team, we assume that the CEO has the final say in the team, and that the forecasts are made by CEOs. ${ }^{7}$ For some firms there may be two CEOs at the same months because of passover, we do not attribute the forecasts disclosed in the meanwhile to anyone. Some CEOs control over two or more different firms, we exclude them from our analysis. The screenings lead to a sample of 8711 forecasts released by 1386 CEOs in 869 different companies. All the variables used in this paper are described in the Appendix.

\subsection{The managerial optimism measure}

Most literature of management earnings forecasts observes whether managers bias their forecasts by weighting each forecast equally. This paper intends to construct a managerial optimism measure on a personal basis; we weight each forecaster equally. Given that a CEO's optimism in assessing future outcome is likely to result in upwardly-biased forecasts, we classify whether a CEO is optimistic if he/she has at least two forecasts and define a CEO to be optimistic if there are more upwardly-biased forecasts than downwardly-biased forecasts during the CEO's tenure. A forecast is defined as upwardbiased if the forecast error is positive, where the definition of forecast error in this paper is

$\mathrm{FE} \equiv$ Managers forecast for earnings before tax - Actual earnings before tax.

However, previous literature confirms that managers may also have other incentives to bias their forecasts. To address the concern that the measure may reflect managers' incentives other than their optimism, we exclude from the measure construction any forecasts that may be contaminated by incentive effects. We detect three potential incentives and then remove forecasts from the sample if they meet any one of the following three criteria:

First, intending to make stock offerings at a favorable price, some firms may temporarily boost their stock price by releasing upwardly-biased forecasts (e.g., Chin et al., 1999; Lang and Lundholm, 2000). Prior evidence is also consistent with this conjecture. ${ }^{8}$ We regard forecasts as possibly tainted by managers' incentives for stock offerings and delete them if a firm conducts an equity offering within 12 months of the forecast. ${ }^{9}$

Second, for employment concerns, managers of financial distressed firms may release upwardly-biased forecasts to mislead investors; even the "cheating" only pertains for a short while. Potential penalties, like legal liability, loss of reputation, and a higher cost of capital, are ineffective in discouraging such forecasts, because managers are unlikely to keep their positions long enough to be punished (e.g., Koch, 1999; Irani, 2003). Empirical evidence

\footnotetext{
${ }^{7}$ Alternative choices are the President of the Board and the Chief Financial Officer (CFO). We repeat our research methodology by assuming the forecast is made by CFO and by President of the Board, respectively. The results are similar under the alternative assumptions (though we do not report them).

${ }^{8}$ See Core (2001) for a survey of evidence from the U.S.; Jelic et al. (1998) for a survey of evidence from British Commonwealth countries; and Chin et al. (1999) for a survey of evidence from Taiwan.

${ }^{9}$ Marquardt and Weidman (1998) document a significantly positive association between managerial participation and voluntary disclosure of earnings forecasts in the nine-month period prior to registration of the offering.
} 
supports the view that managers of financial distressed firms may release upwardly-biased forecasts (e.g., Frost, 1997; Betker et al., 1999; Koch, 1999; Irani, 2003). We collect the dates that firms started experiencing financial distress (as given out by the TEJ) and interpret the forecasts as possibly due to managers' incentives if the firm had experienced financial distress and the forecast is released within 24 months before the distress.

Third, managers may act in self-interest to profit from trading. Managers may publish upwardly-biased (downwardly-biased) forecasts, and then sell (buy) shares. Consistent with this conjecture, Noe (1999) finds that insider trading is higher after the release of a forecast. To detect whether a forecast may be trading-motivated, we collect information on expected earnings and shareholding by directors. ${ }^{10}$ If a forecast is lower (higher) than what the market expected and the company directors increase (decrease) their shareholdings within three months of the forecast, we assume that the forecast is tradingmotivated and delete it. "Expected earnings" is the latest forecast available from either management or analysts for that fiscal year. If there are no such forecasts, we use the actual earnings of the previous year as the market expectations. A concern of this treatment is that it may not capture all the trading-motivated forecasts. The month-end shareholding may be unchanged even though the trading occurs: the directors may acquire (sale) shares and sell (repurchase) them within the same month. Due to the law, however, insiders will not have incentives to do such kind of trading. ${ }^{11}$

Despite all these exclusions, the measure construction process may fail to capture all the forecasts contaminated by incentive effects. For instance, insiders may trade through untraceable accounts. To alleviate this problem, we only examine the last forecast for a fiscal year after discarding all the aforementioned forecasts. Managers in Taiwanese companies often first overestimate the earnings of a fiscal year deliberately to give investors an overly optimistic view of the firms' prospects, and then revise the forecasts downwards later in the fiscal year (e.g., Chin et al., 1999). They will minimize their manipulation in the last forecasts to avoid being punished by the regulatory agency when the forecasts are proven false. ${ }^{12}$

\section{Empirical results}

\subsection{Main results}

Table 1 describes the details in the optimism measure construction process and the regression analysis, and the distribution of the forecasts used to identify CEOs' optimism

\footnotetext{
10 The regulatory agency requires a monthly report from companies on shareholdings by directors at the end of the previous month.

11 To prevent the unfair use of inside information, the Securities and Exchange Law permits the company to recover any profit which the director, supervisor, or manager realizes from any purchase and sale or sale and purchase of any equity security of the company within a period of less than 6 months.

12 The SFC issued the regulation "Guidelines for Disclosure of Financial Forecasts by Public Companies," which permits the firms to revise their forecasts before the actual earnings are published, and stipulates a penalty if the last forecasted earnings diverge more than $20 \%$ from actual earnings. Aside from a penalty, the companies may not be allowed to finance their future capital needs from the capital market.
} 
Table 1

Number and distribution of management forecasts over time, 1985-2002

Panel A: The details in the optimism measure construction process and the regression analysis

\begin{tabular}{lccc}
\hline Number of the sample & Firm & CEO & Forecast \\
Less: forecasts possibly due to incentives rather than optimism: & 869 & 1386 & 8711 \\
1. Forecasts that the firms conduct stock offerings within 12 months \\
of the forecast
\end{tabular}

Less: treatment in the regression analysis

1. Firms with other missing financing data

2. CEOs whose tenure do not contain any whole fiscal years

Subsample analyzed in this paper

$\begin{array}{lll}\underline{412} & \underline{(34)} & \underline{507} \\ \end{array}$

Panel B: Distribution of forecasts used to identify CEOs' optimism over year and over month

\begin{tabular}{|c|c|c|c|}
\hline Year & Number & Month & Number \\
\hline 1985 & 18 & 1 & 108 \\
\hline 1986 & 22 & 2 & 86 \\
\hline 1987 & 36 & 3 & 117 \\
\hline 1988 & 42 & 4 & 228 \\
\hline 1989 & 49 & 5 & 105 \\
\hline 1990 & 47 & 6 & 93 \\
\hline 1991 & 78 & 7 & 83 \\
\hline 1992 & 33 & 8 & 148 \\
\hline 1993 & 52 & 9 & 100 \\
\hline 1994 & 51 & 10 & 231 \\
\hline 1995 & 92 & 11 & 134 \\
\hline 1996 & 86 & 12 & $\underline{326}$ \\
\hline 1997 & 91 & & $1 \overline{759}$ \\
\hline 1998 & 140 & & \\
\hline 1999 & 189 & & \\
\hline 2000 & 234 & & \\
\hline 2001 & 289 & & \\
\hline \multirow[t]{2}{*}{2002} & 210 & & \\
\hline & $1 \overline{759}$ & & \\
\hline
\end{tabular}

over years and over months. In panel A, after removing forecasts that may be contaminated by incentive effects, we have only 2217 forecasts published by 896 different CEOs. Among the 896 CEOs, 355 only have one forecast and dropped, and we are able to classify the other 541 CEOs by the remaining 1862 forecasts. In the regression 
analysis, we further lose some observations. Finally, we analyze a subsample of 1759 forecasts released by 507 CEOs in 412 different companies.

Panel B shows that the number of forecasts increases in years, reflecting that there are more firms listed on TSE and OTC in recent years. We also observe that the number of forecasts is higher in April, August, October, and December. This is probably because in these months, CEOs are more aware of the firms' performance for the requirement of publicizing quarterly financial reports or the end of the fiscal year. The explanation is also consistent with Ami and Ganzach (1998) argument that the forecasters are likely to use the previous actual earnings and modify it on the basis of new information as they predict.

Panel A of Table 2 reports the summary statistics of the CEO data. We see that the tenures of CEOs range from 14 to 214 months, and the average is about 6 years. It is noteworthy that under our classification scheme, there is at most one forecast in a fiscal

Table 2

Summary statistics of the sample

\begin{tabular}{|c|c|c|c|c|c|c|}
\hline Variable name & Obs. & Mean & Median & $\begin{array}{l}\text { Standard } \\
\text { deviations }\end{array}$ & Minimum & Maximum \\
\hline \multicolumn{7}{|l|}{ Panel A: CEO data } \\
\hline Tenure & 507 & 73.59 & 68.00 & 37.74 & 14.00 & 214.00 \\
\hline $\begin{array}{l}\text { Average shareholdings } \\
\text { within tenure }\end{array}$ & 507 & $13,557.31$ & 4648.50 & $34,678.95$ & 1.00 & $406,711.42$ \\
\hline $\begin{array}{l}\text { Average shareholdings } \\
\text { rate within tenure }\end{array}$ & 507 & 6.52 & 3.38 & 8.90 & $1.6 \mathrm{E}-6$ & 59.73 \\
\hline \multicolumn{7}{|l|}{ Panel B: Firm data } \\
\hline \multicolumn{7}{|c|}{ Panel B-1: Variables in the regression analysis } \\
\hline Asset & 2124 & $11,285.20$ & 5008.31 & $22,151.11$ & 343.80 & $317,384.95$ \\
\hline Investment & 2124 & 668.64 & 150.48 & 2495.83 & 36.00 & $75,296.64$ \\
\hline $\begin{array}{l}\text { Investment normalized } \\
\text { by lagged assets }\end{array}$ & 2124 & 0.06 & 0.03 & 0.09 & $2.0 \mathrm{E}-5$ & 1.53 \\
\hline Cash flow & 2124 & 1191.56 & 397.14 & 3142.70 & -6436.51 & $77,418.26$ \\
\hline $\begin{array}{l}\text { Cash flow normalized } \\
\text { by lagged assets }\end{array}$ & 2124 & 0.11 & 0.10 & 0.10 & -0.28 & 1.10 \\
\hline$Q$ & 2124 & 0.97 & 0.94 & 0.44 & 0.13 & 2.77 \\
\hline \multicolumn{7}{|c|}{ Panel B-2: Classifications that are ranking the firms and defining firms' more constraints } \\
\hline Dividend payout & 355 & 36.76 & 33.33 & 16.67 & 5.56 & 100.00 \\
\hline Interest coverage & 412 & 18.95 & 15.47 & 20.30 & -95.65 & 148.33 \\
\hline Firm size & 412 & 9058.71 & 3774.54 & $18,182.41$ & 478.57 & $169,715.78$ \\
\hline Age & 412 & 9.90 & 7.00 & 8.80 & 2.00 & 41.00 \\
\hline Ownership concentration & 412 & 26.77 & 24.41 & 12.91 & 6.74 & 76.94 \\
\hline $\begin{array}{l}\text { Cash flow right of the } \\
\text { controlling shareholder }\end{array}$ & 164 & 13.94 & 11.00 & 11.99 & 0.00 & 66.02 \\
\hline
\end{tabular}

All variables except age are over 1985-2002. The definitions of the variables refer to the Appendix. Tenure is in months; average shareholdings within tenure is in thousand shares; average shareholdings rate within tenure, dividend payout, interest coverage, ownership concentration, and cash flow right of the controlling shareholder are in percentage; asset, investment, and cash flow are in million of new Taiwan dollars; age is in years. Due to a lack of data, some classifications for defining firms' more constraints may not include all of the firms in the regressions. 
year. The numbers of forecasts CEOs have are consequently related to their tenures. Because the CEOs may not be replaced in the beginning of the fiscal year, CEOs may have two forecasts without a 2-year tenure.

Panel B of Table 2 reports the summary statistics of the firm data. Dropping the sample that the CEO is replaced during the year, we have 2124 observations in the regressions. In each classification for more constrained firms except industry and business group affiliation, under our classification scheme, the number of constrained firms and that of unconstrained firms are both a half of the firms in the regressions. There are 356 firms are classified as manufacturing (and constrained) and 56 are non-manufacturing (and unconstrained). As for the business group affiliation classification, we find that 161 firms are in large groups and 251 firms are not.

Table 3 presents the classification results of the CEOs. We find that $69 \%$ of the CEOs are classified as optimistic. In addition, most CEOs display optimism at all levels of forecast number. Excluding forecasts that may be contaminated by incentive effects, we conjecture that managerial optimism may be a possible reason for the upward bias of management forecasts in Taiwan.

Table 4 presents the OLS regression coefficients for the investment-cash flow sensitivity. Column 1 in panel A confirms the results of prior literature (e.g., Fazzari et al., 1988; Schaller, 1993; and many others). The coefficient on $Q$ is significantly positive, indicating that investment increases in the underlying investment opportunity as predicted by Tobin (1969) Q-theory. We also find that the cash flow has a significantly positive explanatory power for investment, suggesting that managers will be more willing to invest when internal funds are available. The finding can be explained by the agency or the information asymmetry view. Under the agency theory, managers will invest more to pursue self-interests when internal funds are available (e.g., Jensen, 1986). The information asymmetry view suggests that information between corporate insiders and the capital market causes good firms being undervalued. Therefore, managers in good firms will under-invest if they have no financial slacks (e.g., Myers and Majluf, 1984).

Table 3

Proportion of optimistic CEOs

\begin{tabular}{lllll}
\hline $\begin{array}{l}\text { Number of forecasts } \\
\text { CEOs have }\end{array}$ & $\begin{array}{l}\text { Number of } \\
\text { total CEOs }\end{array}$ & $\begin{array}{l}\text { Number of } \\
\text { optimistic CEOs }\end{array}$ & $\begin{array}{l}\text { Number of } \\
\text { non-optimistic CEOs }\end{array}$ & $\begin{array}{l}\text { Proportion of } \\
\text { optimistic CEOs (\%) }\end{array}$ \\
\hline 2 & 212 & 147 & 65 & 69.34 \\
3 & 123 & 89 & 34 & 72.36 \\
4 & 61 & 43 & 18 & 70.49 \\
5 & 43 & 25 & 18 & 58.14 \\
6 & 27 & 18 & 9 & 66.67 \\
7 & 17 & 14 & 3 & 82.35 \\
$\geqq 8$ & 24 & 14 & 10 & 58.33 \\
Total & 507 & 350 & 157 & 69.03 \\
\hline
\end{tabular}

This table presents the proportion of optimistic CEOs in Taiwanese companies under our measure. We identify whether the CEO is optimistic if he/she has at least two forecasts, and classify CEOs as optimistic if there are more upwardly-biased forecasts than downwardly-biased forecasts during their tenure. 
Table 4

OLS regressions of investment on cash flow and optimism measure

Panel A: Full sample and more constrained subsample firms

\begin{tabular}{|c|c|c|c|c|c|c|c|c|c|c|}
\hline & \multirow{2}{*}{\multicolumn{2}{|c|}{ Full sample }} & \multicolumn{8}{|c|}{ More constrained subsample firms } \\
\hline & & & $\begin{array}{l}\text { Dividend } \\
\text { payout }\end{array}$ & $\begin{array}{l}\text { Interest } \\
\text { coverage }\end{array}$ & Size & Age & $\begin{array}{l}\text { Group } \\
\text { affiliation }\end{array}$ & Industry & $\begin{array}{l}\text { Ownership } \\
\text { concentration }\end{array}$ & $\begin{array}{l}\text { Cash flow } \\
\text { right }\end{array}$ \\
\hline Intercept $(\times 100)$ & $1.68 * * *$ & $1.81 * *$ & $4.09 * * *$ & $3.38 * * *$ & $1.85^{*}$ & 3.06 & $3.37 * * *$ & $2.85 * * *$ & $3.25 * * *$ & $5.66 * * *$ \\
\hline Cash flow & $0.22 * * *$ & $0.10^{*}$ & $0.19 * *$ & $0.09 *$ & $0.14 *$ & $0.25 * *$ & 0.10 & $0.11 * *$ & $0.10^{*}$ & -0.02 \\
\hline$Q(\times 100)$ & $2.51 * * *$ & $3.15^{* * *}$ & -0.04 & $0.79 * * *$ & $1.19^{* * *}$ & 0.22 & 0.45 & $0.84 * * *$ & 0.55 & $0.55 * * *$ \\
\hline Optimism measure $(\times 100)$ & & $-1.32 * *$ & $-2.53 * *$ & $-1.44^{*}$ & 0.57 & -1.17 & -1.24 & $-1.25^{*}$ & -1.17 & $-4.68 * * *$ \\
\hline Cash flow $\times Q$ & & 0.01 & $0.04 *$ & -0.01 & -0.04 & 0.01 & 0.02 & 0.01 & 0.03 & 0.01 \\
\hline Cash flow $\times$ optimism measure & & $0.19 * * *$ & $0.31 * * *$ & $0.17 * * *$ & 0.10 & $0.31 * * *$ & $0.27 * * *$ & $0.28 * * *$ & $0.30 * * *$ & $0.49 * * *$ \\
\hline Adjusted $R^{2}$ & 0.11 & 0.13 & 0.22 & 0.13 & 0.06 & 0.22 & 0.15 & 0.15 & 0.17 & 0.14 \\
\hline Observations & 2124 & 2124 & 788 & 1027 & 729 & 623 & 989 & 1834 & 1167 & 626 \\
\hline \multicolumn{11}{|c|}{ Panel B: Less constrained subsample firms } \\
\hline & $\begin{array}{l}\text { Dividend } \\
\text { payout }\end{array}$ & \multicolumn{2}{|c|}{$\begin{array}{l}\text { Interest } \\
\text { coverage }\end{array}$} & Size & Age & \multicolumn{2}{|c|}{$\begin{array}{l}\text { Group } \\
\text { affiliation }\end{array}$} & Industry & $\begin{array}{l}\text { Ownership } \\
\text { concentration }\end{array}$ & $\begin{array}{l}\text { Cash flow } \\
\text { right }\end{array}$ \\
\hline Intercept $(\times 100)$ & $1.83^{* *}$ & \multicolumn{2}{|c|}{1.65} & $3.07 * * *$ & $1.89 * * *$ & \multicolumn{2}{|c|}{$2.41 * *$} & 2.09 & $2.71 * * *$ & 2.03 \\
\hline Cash flow & $0.10 * *$ & \multicolumn{2}{|c|}{$0.23 * *$} & $0.19 * * *$ & $0.13^{* *}$ & \multicolumn{2}{|c|}{$0.15^{* *}$} & $0.33 * *$ & $0.12 * *$ & 0.12 \\
\hline$Q(\times 100)$ & $1.32 * * *$ & \multicolumn{2}{|c|}{-0.40} & $0.80 * * *$ & $1.61 * * *$ & \multicolumn{2}{|c|}{$1.11 * * *$} & $1.15^{* *}$ & $0.69 * * *$ & $0.95 * *$ \\
\hline Optimism measure $(\times 100)$ & 0.29 & \multicolumn{2}{|c|}{0.73} & $-2.45 * * *$ & 0.17 & -1.13 & & -0.27 & -1.05 & 1.00 \\
\hline Cash flow $\times Q$ & -0.01 & & $11 * * *$ & -0.01 & $-0.03 * * *$ & -0.02 & & 0.08 & -0.01 & -0.01 \\
\hline Cash flow $\times$ optimism measure & -0.05 & 0.1 & & 0.09 & 0.09 & 0.21 & $1 * * *$ & 0.08 & $0.20 * * *$ & 0.12 \\
\hline Adjusted $R^{2}$ & 0.10 & 0.2 & & 0.16 & 0.08 & 0.13 & & 0.08 & 0.11 & 0.08 \\
\hline Observations & 1073 & 1097 & & 1395 & 1501 & 1135 & & 90 & 953 & 651 \\
\hline
\end{tabular}

The dependent variable is investment. The definitions of the variables refer to the Appendix. To avoid possible distortion caused by firm size discrepancy, we normalize the investment and the cash flow by total assets at the beginning of the fiscal year. The alternative hypothesis is that the coefficient on the interaction of cash flow and the optimism measure is positive. ${ }^{* *}, * *$, and $*$ denote significant levels at $1 \%, 5 \%$, and $10 \%$, respectively. 
Column 2 in panel A further provide evidence that aside from agency and information asymmetry view, managerial optimism may also be an explanation to impact the investment-cash flow sensitivity. We see that the coefficient on interaction term of cash flow with the optimism dummy variable is positive and significant at a $1 \%$ level. We also find that the cash flow still has a significantly positive explanatory power for investment, suggesting that non-optimistic managers will be more willing to invest when internal funds are available. The sum of the coefficients on cash flow and on the optimism measure-cash flow interaction term is positive, suggesting that optimistic managers will be more willing to invest when internal funds are available.

Columns 3-10 in panel A report the OLS regression coefficients for the more constrained subsample. We observe that the coefficients on the optimism measure-cash flow interaction term range from 0.10 to 0.49 . Moreover, the coefficients are significant at a $1 \%$ level for seven out of eight classifications. This is consistent with the hypothesis that in constrained firms, the investment-cash flow sensitivities are larger for optimistic managers than non-optimistic managers.

Malmendier and Tate (2005) argue that a second empirical implication of Heaton (2002) conjecture is that optimism should matter more for firms more financing constrained. To further ensure that our hypothesis is supported, we run regressions of investment on cash flow and optimism measure using less constrained subsample firms. Panel B of Table 4 presents the OLS regression results. Contrary to large and significance of the coefficients on the optimism measure-cash flow interaction term in more constrained firms, those in less constrained firms range only from -0.05 to 0.21 and insignificant over half of the eight classifications. Comparing the coefficient on the interaction terms of more constrained firms with that of less constrained firms, we find that all the coefficients of more constrained firms are larger than those of less constrained firms. The difference of the coefficients ranges from 0.01 to 0.37 . The finding is consistent with Malmendier and Tate (2005) argument and further supports the hypothesis.

\subsection{Is the significance related to agency or information asymmetry problems?}

One may concern that our results are related to traditional agency or information asymmetry problems. We now ask whether our results are robust after controlling agency and information asymmetry problems. Holmstrom (1982) argues that since a competitive labor market is trying to learn about young managers' abilities, behaviors of young managers are different from those of old managers and a number of distortions occur. Chevalier and Ellison (1999) also find supporting evidence that younger American mutual fund managers adopt herding behaviors due to career concern. Here we examine whether CEOs have different investment behaviors when they get older. Constructing a dummy variable that equals 1 if the investment policy is observed during the first 3 years of the CEO's tenure and equals 0 if not, we include the early-in-tenure dummy variable and the interaction of the early-in-tenure dummy variable in the regressions. The positive and significance of the coefficients on the optimism measurecash flow interaction term should be unchanged after including these supplementary variables. 
OLS regressions of investment on cash flow, early-in-tenure dummy variable, and optimism measure Panel A: Full sample and more constrained subsample firms

\begin{tabular}{|c|c|c|c|c|c|c|c|c|c|c|}
\hline & \multirow[t]{2}{*}{ Full sample } & & \multicolumn{8}{|c|}{ More constrained subsample firms } \\
\hline & & & $\begin{array}{l}\text { Dividend } \\
\text { payout }\end{array}$ & $\begin{array}{l}\text { Interest } \\
\text { coverage }\end{array}$ & Size & Age & $\begin{array}{l}\text { Group } \\
\text { affiliation }\end{array}$ & Industry & $\begin{array}{l}\text { Ownership } \\
\text { concentration }\end{array}$ & $\begin{array}{l}\text { Cash flow } \\
\text { right }\end{array}$ \\
\hline Intercept $(\times 100)$ & $1.46^{* * *}$ & $3.32 * *$ & $4.83 * * *$ & $3.27 * * *$ & 1.54 & $4.31 * *$ & $3.88 * * *$ & $3.26^{* * *}$ & $3.99 * * *$ & $7.06 * * *$ \\
\hline Cash flow & $0.16^{* * *}$ & 0.01 & 0.02 & 0.05 & 0.07 & $-0.02 * *$ & -0.05 & $-0.01 * *$ & -0.05 & $-0.24 * *$ \\
\hline$Q(\times 100)$ & $1.22 * * *$ & $0.85 * * *$ & 0.06 & $0.77 * * *$ & $1.14 * * *$ & 0.16 & $0.60 *$ & $0.89 * * *$ & $0.65^{*}$ & $0.82 *$ \\
\hline Early in tenure $(\times 100)$ & 0.30 & -0.09 & -1.21 & 0.69 & 1.00 & -1.45 & -0.84 & 0.01 & -0.65 & -1.92 \\
\hline Optimism measure $(\times 100)$ & & $-1.75^{* *}$ & $-2.56^{* *}$ & $-1.74 * *$ & 0.13 & -1.79 & -1.51 & $-1.79 * *$ & -1.74 & $-5.36 * * *$ \\
\hline Cash flow $\times Q$ & $-0.03 * * *$ & -0.01 & 0.03 & -0.01 & -0.03 & -0.01 & 0.01 & -0.01 & 0.02 & -0.02 \\
\hline Cash flow $\times$ early in tenure & $0.11 * *$ & $0.15 * * *$ & $0.24 * * *$ & 0.03 & 0.06 & $0.34 * * *$ & $0.24 * * *$ & $0.15^{* * *}$ & $0.23 * * *$ & $0.37 * * *$ \\
\hline Cash flow $\times$ optimism measure & & $0.28 * * *$ & $0.33 * * *$ & $0.18 * * *$ & $0.13 *$ & $0.42 * * *$ & $0.28 * * *$ & $0.32 * * *$ & $0.34 * * *$ & $0.51 * * *$ \\
\hline Adjusted $R^{2}$ & 0.12 & 0.15 & 0.23 & 0.13 & 0.07 & 0.24 & 0.16 & 0.16 & 0.19 & 0.17 \\
\hline Observations & 2124 & 2124 & 788 & 1027 & 729 & 623 & 989 & 1834 & 1167 & 626 \\
\hline \multicolumn{11}{|c|}{ Panel B: Less constrained subsample firms } \\
\hline & $\begin{array}{l}\text { Dividend } \\
\text { payout }\end{array}$ & $\begin{array}{l}\text { Interest } \\
\text { coverage }\end{array}$ & \multicolumn{2}{|l|}{ Size } & Age & $\begin{array}{l}\text { Group } \\
\text { affiliation }\end{array}$ & \multicolumn{2}{|c|}{ Industry } & $\begin{array}{l}\text { Ownership } \\
\text { concentration }\end{array}$ & $\begin{array}{l}\text { Cash flow } \\
\text { right }\end{array}$ \\
\hline Intercept $(\times 100)$ & 1.22 & $2.67 *$ & \multicolumn{2}{|c|}{$4.18 * * *$} & $1.90 * *$ & $2.47 * *$ & \multicolumn{2}{|c|}{2.65} & $2.51 * * *$ & 1.34 \\
\hline Cash flow & $0.11 *$ & -0.03 & \multicolumn{2}{|c|}{0.03} & 0.09 & $0.09 * *$ & \multicolumn{2}{|c|}{0.20} & 0.07 & 0.15 \\
\hline$Q(\times 100)$ & $1.25^{* * *}$ & -0.31 & \multicolumn{2}{|c|}{$0.89 * * *$} & $1.56 * * *$ & $1.04 * * *$ & \multicolumn{2}{|c|}{$1.32 * * *$} & $0.68 * * *$ & $0.74 * *$ \\
\hline Early in tenure $(\times 100)$ & $1.62 * *$ & $-1.86^{* *}$ & \multicolumn{2}{|c|}{-0.83} & 0.71 & 0.78 & \multicolumn{2}{|c|}{-1.38} & 0.76 & $2.77 * *$ \\
\hline Optimism measure $(\times 100)$ & 0.16 & 0.53 & \multicolumn{2}{|c|}{$-3.21 * * *$} & -0.06 & -1.43 & \multicolumn{2}{|c|}{-0.19} & $-1.37^{*}$ & 0.89 \\
\hline Cash flow $\times Q$ & -0.01 & $0.09 * * *$ & \multicolumn{2}{|c|}{$-0.02 *$} & $-0.03 * *$ & -0.02 & \multicolumn{2}{|c|}{-0.05} & -0.01 & 0.01 \\
\hline Cash flow $\times$ early in tenure & -0.03 & $0.48 * * *$ & \multicolumn{2}{|c|}{$0.21 * * *$} & 0.04 & 0.06 & \multicolumn{2}{|c|}{$0.23 *$} & 0.06 & -0.11 \\
\hline Cash flow $\times$ optimism measure & 0.05 & $0.17^{*}$ & \multicolumn{2}{|c|}{$0.17 * * *$} & 0.06 & \multirow{2}{*}{$\begin{array}{l}0.24 * * * \\
0.14\end{array}$} & \multicolumn{2}{|c|}{-0.11} & $0.20 * * *$ & 0.13 \\
\hline Adjusted $R^{2}$ & 0.10 & 0.23 & \multicolumn{2}{|c|}{0.16} & 0.09 & & 0.0 & & 0.11 & 0.08 \\
\hline Observations & 1073 & 1097 & 1395 & & 1501 & 1135 & 290 & & 953 & 651 \\
\hline
\end{tabular}

The dependent variable is investment. The dummy variable "early-in-tenure" equals 1 if the investment policy is observed before the third year of the CEO's tenure and equals 0 if not. The definitions of other variables refer to the Appendix. To avoid the possible distortion caused by firm size discrepancy, we normalize the investment and the cash flow by total assets at the beginning of the fiscal year. The alternative hypothesis is that the coefficient on the interaction of cash flow and the optimism measure is positive. ***, **, and $*$ denote significant levels at $1 \%, 5 \%$, and $10 \%$, respectively. 
Table 5 presents the OLS regression coefficients after controlling the early-in-tenure dummy variable. Panel A reports the results of full sample and more constrained firms. We find that the coefficients on the optimism measure-cash flow interaction term are still significantly positive. Panel B presents the results of less constrained subsample firms. We also observe that for most of eight classifications the coefficients of more constrained firms on the optimism measure-cash flow interaction term are still larger than those of less constrained firms. These findings confirm the hypothesis. We further observe that the coefficients of the interaction of the early-in-tenure dummy variable and cash flow are significantly positive for the full sample. A possible explanation is that the labor market is unfamiliar with the CEOs' ability whey they just got the job. Therefore, the CEOs' investment behavior is more dependent on the internal cash flow. For the more constrained subsample, the coefficients on the interaction terms of the early-intenure dummy variable and cash flow are all positive and significant for six of the eight classifications.

An alternative way to control agency and information asymmetry problems is through the firm characteristics tied to problems of agency or information asymmetry, i.e. size, age, group affiliation, industry, ownership concentration, and cash flow right of the controlling shareholder. Specifically, among the classifications, the "dividend payout" and the "interest coverage" are directly related to the firms' financing ability. For the two classifications, respectively, we re-split only the more constrained subsample firms into two groups through the characteristics tied to problems of agency or information asymmetry. We define six dummy variables that equal 1 if among these more constrained subsamples, firms are classified as more likely to face the agency or information asymmetry problems and 0 if they are not. Then in the regressions we include, respectively, the dummy variables and the interaction of the dummy variable. Table 6 reports the estimates of OLS regression coefficients. Panels A and B, respectively, present the more constrained subsample for the "dividend payout" and the "interest coverage" classifications. We find that controlling for these dummy variables does not affect the relation between investment and managerial optimism. Moreover, most of the coefficients on the interaction term of cash flow with the agency/information asymmetry dummy variable are significantly positive. This is consistent with the traditional explanation that firms with larger agency or information asymmetry problems have larger investment-cash flow sensitivity (e.g., Fazzari et al., 1988; Schaller, 1993; and many others). So far, the hypothesis is still supported after controlling agency or information asymmetry problems.

\subsection{Is the optimism measure proper?}

Another concern for our results is that the optimism measure is improper. For instance, the optimism measure may be related to agency or information asymmetry problems. As a consequence, the significance of the optimism measure-cash flow interaction coefficients may be in fact a result of agency or information asymmetry problems rather than optimism. A priori, it is hard to say that the CEOs with more upward-bias forecasts face more agency or asymmetric information problems than those with more downward-bias forecasts. Nevertheless, to take this concern into account, we 
Table 6

OLS regressions controlling for the characteristics tied to problems of agency or information asymmetry

Panel A: More constrained subsample under the "dividend payout" classification

\begin{tabular}{|c|c|c|c|c|c|c|c|}
\hline & \multirow[t]{2}{*}{ Without control } & \multicolumn{4}{|c|}{ Control dummy variable for information asymmetry problem } & \multicolumn{2}{|c|}{ Control dummy variable for agency problem } \\
\hline & & Size & Age & Group affiliation & Industry & Ownership concentration & Cash flow right \\
\hline Intercept $(\times 100)$ & $4.09 * * *$ & $2.46^{*}$ & $4.87 * * *$ & $4.53^{* * *}$ & $3.39 *$ & $4.92 * * *$ & $8.97 * * *$ \\
\hline Cash flow & $0.19 * *$ & $0.43^{* * *}$ & 0.05 & $0.17^{*}$ & -0.19 & -0.01 & $-0.44 * *$ \\
\hline$Q(\times 100)$ & -0.04 & $0.26 * *$ & 0.20 & -0.07 & 0.06 & 0.13 & -0.69 \\
\hline Agency/information asymmetry dummy variable & & $0.02 * *$ & $-0.02 * *$ & -0.01 & 0.01 & -0.01 & -0.03 \\
\hline Optimism measure $(\times 100)$ & $-2.53^{* *}$ & -2.05 & $-2.58 * *$ & $-2.48 *$ & $-2.26 *$ & $-2.57 * *$ & $-4.92 * *$ \\
\hline Cash flow $\times Q$ & $0.04 *$ & -0.01 & 0.02 & $0.04^{*}$ & 0.04 & 0.03 & $0.12 * * *$ \\
\hline $\begin{array}{l}\text { Cash flow } \times \text { agency/information asymmetry } \\
\text { dummy variable }\end{array}$ & & $-0.44^{* * *}$ & $0.27 * * *$ & 0.04 & $0.39 * *$ & $0.32 * * *$ & $0.41^{* * *}$ \\
\hline Cash flow $\times$ optimism measure & $0.31 * * *$ & $0.27 * * *$ & $0.34 * * *$ & $0.31 * * *$ & $0.33^{* * *}$ & $0.33 * * *$ & $0.33^{* * *}$ \\
\hline Adjusted $R^{2}$ & 0.22 & 0.26 & 0.24 & 0.22 & 0.24 & 0.25 & 0.29 \\
\hline & \multirow[t]{2}{*}{ Without control } & \multicolumn{4}{|c|}{ Control dummy variable for information asymmetry problem } & \multicolumn{2}{|c|}{ Control dummy variable for agency problem } \\
\hline & & Size & Age & Group affiliation & Industry & Ownership concentration & Cash flow right \\
\hline Intercept $(\times 100)$ & $3.38^{* * *}$ & $2.90^{* * *}$ & $3.48^{* * *}$ & $3.27 * * *$ & $5.26^{* * *}$ & $2.99 * * *$ & $3.28^{* * *}$ \\
\hline Cash flow & $0.09^{*}$ & $0.18^{* * *}$ & 0.05 & 0.08 & -0.07 & 0.07 & 0.05 \\
\hline$Q(\times 100)$ & $0.79 * * *$ & $0.93^{* * *}$ & $1.09^{* * *}$ & $0.79^{* * *}$ & $0.87^{* * *}$ & $0.67^{* * *}$ & $1.25^{* * *}$ \\
\hline Agency/information asymmetry dummy variable & & 0.06 & $-0.02 * *$ & 0.01 & $-0.02 * *$ & 0.01 & -0.01 \\
\hline Optimism measure $(\times 100)$ & $-1.44 *$ & $-1.62 * *$ & -0.65 & $-1.42^{*}$ & $-1.42^{*}$ & -1.01 & 0.01 \\
\hline Cash flow $\times Q$ & -0.01 & -0.02 & -0.02 & -0.01 & -0.01 & 0.01 & -0.02 \\
\hline $\begin{array}{l}\text { Cash flow } \times \text { agency/information asymmetry } \\
\text { dummy variable }\end{array}$ & & $-0.18^{* * *}$ & $0.19^{* * *}$ & 0.01 & $0.18^{* *}$ & $0.08^{*}$ & 0.07 \\
\hline Cash flow $\times$ optimism measure & $0.17^{* * * *}$ & $0.18^{* * *}$ & $0.09 * *$ & $0.16^{* * *}$ & $0.17^{* * *}$ & $0.14^{* * *}$ & 0.05 \\
\hline Adjusted $R^{2}$ & 0.13 & 0.15 & 0.15 & 0.13 & 0.13 & 0.14 & 0.05 \\
\hline
\end{tabular}

This table reports the coefficients of the regressions controlling for the agency/information asymmetry dummy variables. For the "dividend payout" and the "interest coverage" classifications, respectively, we re-split only the more constrained subsample firms into two groups through the characteristics tied to problems of agency or information asymmetry and define the agency/information dummy variables $D$ that equal 1 if these more constrained firms are classified as more likely to face the agency or information asymmetry problems and 0 if they are not. The regression specification is:

$I_{i t}=\beta_{1}+\beta_{2} C_{i t}+\beta_{3} Q_{i t-1}+\beta_{4} D_{i}+\beta_{5} O_{i}+\beta_{6} C_{i t} Q_{i t-1}+\beta_{7} C_{i t} D_{i}+\beta_{8} C_{i t} O_{i}+\varepsilon_{i t}$

where $I$ is investment, $C$ is cash flow from operation, $O$ is the ratio of market value to book value, $D_{i}$ is the agency/information dummy variable, and $O$ is the dummy variable which is 1 if the CEO is classified optimistic and 0 if he/she is not. To avoid the possible distortion caused by firm size discrepancy, we normalize the investment and the cash flow by total assets at the beginning of the fiscal year. The alternative hypothesis is that $\beta_{8}$ is positive. The $* * *, * *$, and $*$ denote significant levels at $1 \%, 5 \%$, and $10 \%$, respectively. 
Table 7

The optimism measure and characteristics tied to problems of agency or information asymmetry

\begin{tabular}{|c|c|c|c|c|c|c|}
\hline \multirow[t]{2}{*}{ Proxy } & \multicolumn{2}{|c|}{ Number of } & \multicolumn{2}{|c|}{ Average of } & \multirow{2}{*}{$\begin{array}{l}\text { Absolute value } \\
\text { of } t \text {-statistic }\end{array}$} & \multirow[t]{2}{*}{$P$-value } \\
\hline & $\begin{array}{l}\text { Optimistic } \\
\text { CEOs }\end{array}$ & $\begin{array}{l}\text { Non-optimistic } \\
\text { CEOs }\end{array}$ & $\begin{array}{l}\text { Optimistic } \\
\text { CEOs }\end{array}$ & $\begin{array}{l}\text { Non-optimistic } \\
\text { CEOs }\end{array}$ & & \\
\hline Firm size & 350 & 157 & $8,830.72$ & $11,992.32$ & 1.19 & 0.1176 \\
\hline Age & 350 & 157 & 11.32 & 12.88 & 1.26 & 0.1048 \\
\hline Ownership concentration & 350 & 157 & 26.10 & 27.39 & 0.47 & 0.3193 \\
\hline $\begin{array}{l}\text { Cash flow right of the } \\
\text { controlling shareholder }\end{array}$ & 149 & 78 & 13.74 & 13.47 & 0.17 & 0.4339 \\
\hline
\end{tabular}

The table presents the results of the test that whether the CEOs classified as optimistic face a larger agency or information asymmetry problem. We apply four firms' characteristics tied to problems of agency or asymmetric information such as size, age, ownership concentration, and cash flow right of the controlling shareholder. The definitions of the characteristics refer to the Appendix. For each characteristic, we calculate the average value of the characteristics for each CEO during his/her tenure; then we compute the average of optimistic CEOs and nonoptimistic CEOs, respectively. Firm size is in million of new Taiwan dollars. Ownership concentration and cash flow right are in percentage. Age is in years. The null hypothesis is that for each characteristic, the average number of optimistic CEOs equals that of non-optimistic CEOs. $P$-values are for one-tailed tests. Due to a lack of data, some characteristics may not include all of the CEOs in the regressions.

use four firm characteristics tied to problems of agency or asymmetric information such as size, age, ownership concentration, and cash flow right of the controlling shareholder to observe if the CEOs classified as optimistic face larger agency or asymmetric information problems. If our the optimism measure is related to agency or information asymmetry problems, we should see that the CEOs classified as optimistic here control smaller, younger, less concentrated, or less cash holding firms, i.e. firms with larger agency or information asymmetry problems. In Table 7, we calculate, for each characteristic, the average value of the characteristics for each CEO during his/her tenure; then we compute the average of optimistic CEOs and non-optimistic CEOs, respectively. The null hypothesis is that for each characteristic, the average number of optimistic CEOs is equal to that of non-optimistic CEOs. That is, if our optimism measure is related to agency or information asymmetry problems, a significantly difference between the two averages should be observed. For instance, if optimistic CEOs bear a larger information asymmetry problem because of their firm size, the average firm size of optimistic CEOs should be smaller than that of non-optimistic CEOs. Results in Table 7, however, do not support this conjecture. For all of the four characteristics, none of them exhibit a significant difference between optimistic and nonoptimistic CEOs.

The optimism measure used as independent variable above is defined using the whole sample period, which implies that the optimism is fixed over time. One may argue that managerial optimism may be time-varying. To tackle this concern, we also define the optimism using only the forecasts prior to the investment period with a 1year gap. That is, for each observation in year $t$ in the regression, we define that CEO's optimism using forecasts in the period before year $t-1$. This definition allows the managerial optimism to become time-varying; that is, for a CEO's investment behaviors in two different years, the corresponding managerial optimism for that $\mathrm{CEO}$ 
Table 8

OLS regressions of investment on cash flow and time-varying optimism measure

Panel A: Full sample and more constrained subsample firms

\begin{tabular}{|c|c|c|c|c|c|c|c|c|c|c|}
\hline & \multirow{2}{*}{\multicolumn{2}{|c|}{ Full sample }} & \multicolumn{8}{|c|}{ More constrained subsample firms } \\
\hline & & & $\begin{array}{l}\text { Dividend } \\
\text { payout }\end{array}$ & $\begin{array}{l}\text { Interest } \\
\text { coverage }\end{array}$ & Size & Age & $\begin{array}{l}\text { Group } \\
\text { affiliation }\end{array}$ & Industry & $\begin{array}{l}\text { Ownership } \\
\text { concentration }\end{array}$ & $\begin{array}{l}\text { Cash flow } \\
\text { right }\end{array}$ \\
\hline Intercept $(\times 100)$ & $2.08 * * *$ & $3.39 * * *$ & $3.47 * * *$ & $2.38 * *$ & $1.64 *$ & $3.23 * *$ & $3.82 * * *$ & $3.34 * * *$ & $2.70 * * *$ & $3.97 * * *$ \\
\hline Cash flow & $0.15^{* * *}$ & 0.04 & 0.08 & 0.05 & $0.12 *$ & 0.08 & 0.01 & 0.04 & 0.09 & -0.07 \\
\hline$Q(\times 100)$ & $0.88 * * *$ & $1.32 * * *$ & $1.75 * * *$ & $1.69 * * *$ & $2.08 * * *$ & -0.07 & $1.19 * * *$ & $1.23 * * *$ & $1.97 * * *$ & $1.72 * * *$ \\
\hline Optimism measure $(\times 100)$ & & $-2.23 * * *$ & $-2.43 * *$ & $-2.07 * *$ & -0.49 & -1.48 & $-2.31 * *$ & $-2.20 * * *$ & $-1.70^{*}$ & $-3.58 * * *$ \\
\hline Cash flow $\times Q$ & & -0.01 & -0.03 & -0.01 & $-0.06^{*}$ & $0.05 * *$ & 0.02 & 0.01 & -0.02 & -0.01 \\
\hline Cash flow $\times$ optimism measure & & $0.16^{* * *}$ & $0.16^{* *}$ & $0.19 * * *$ & 0.04 & $0.22 * *$ & 0.10 & $0.17 * * *$ & 0.07 & $0.27 * * *$ \\
\hline Adjusted $R^{2}$ & 0.12 & 0.13 & 0.10 & 0.16 & 0.12 & 0.34 & 0.15 & 0.15 & 0.15 & 0.15 \\
\hline Observations & 1042 & 1042 & 342 & 485 & 258 & 167 & 385 & 896 & 607 & 364 \\
\hline \multicolumn{11}{|c|}{ Panel B: Less constrained subsample firms } \\
\hline & $\begin{array}{l}\text { Dividend } \\
\text { payout }\end{array}$ & $\begin{array}{l}\text { Interest } \\
\text { coverage }\end{array}$ & \multicolumn{2}{|c|}{ Size } & Age & $\begin{array}{l}\text { Group } \\
\text { affiliation }\end{array}$ & \multicolumn{2}{|c|}{ Industry } & $\begin{array}{l}\text { Ownership } \\
\text { concentration }\end{array}$ & $\begin{array}{l}\text { Cash flow } \\
\text { right }\end{array}$ \\
\hline Intercept $(\times 100)$ & $1.71 *$ & $4.06 * * *$ & \multicolumn{2}{|c|}{$4.13^{* * *}$} & $2.45 * * *$ & $3.07 * * *$ & \multicolumn{2}{|c|}{3.25} & $3.76^{* * *}$ & $3.00 * *$ \\
\hline Cash flow & $0.15^{* *}$ & 0.04 & \multicolumn{2}{|c|}{0.01} & $0.10 * *$ & 0.07 & \multicolumn{2}{|c|}{0.07} & 0.03 & 0.16 \\
\hline$Q(\times 100)$ & $1.51 * * *$ & $0.97 * *$ & \multicolumn{2}{|c|}{$1.15^{* * *}$} & $2.07 * * *$ & $1.38 * * *$ & \multicolumn{2}{|c|}{$2.05 * * *$} & $0.70 *$ & $1.21 * *$ \\
\hline Optimism measure $(\times 100)$ & -0.27 & $-2.34 * *$ & -3 & $.10^{* * *}$ & -0.99 & $-2.19 * *$ & -1.6 & & $-2.83 * *$ & 0.07 \\
\hline Cash flow $\times Q$ & -0.02 & 0.02 & & .01 & $-0.04 * *$ & -0.01 & -0.0 & & 0.01 & -0.02 \\
\hline Cash flow $\times$ optimism measure & -0.11 & 0.11 & & $.21 * * *$ & -0.04 & $0.20 * * *$ & 0.0 & & $0.24 * * *$ & 0.18 \\
\hline Adjusted $R^{2}$ & 0.16 & 0.10 & & .14 & 0.12 & 0.12 & 0.0 & & 0.12 & 0.08 \\
\hline Observations & 571 & 557 & 784 & & 875 & 657 & 146 & & 435 & 369 \\
\hline
\end{tabular}

The dependent variable is investment. The optimism measure is defined by using only the forecasts prior to the period investment is observed with a 1-year gap. The definitions of other variables refer to the Appendix. To avoid the possible distortion caused by firm size discrepancy, we normalize the investment and the cash flow by total assets at the beginning of the fiscal year. The alternative hypothesis is that the coefficient on the interaction of cash flow and the optimism measure is positive. $* * *$, $* *$, and $*$ denote significant levels at $1 \%, 5 \%$, and $10 \%$, respectively. 
Table 9

Results for the tests on the hypothesis under the managerial optimism measure constructed from stockholdings

Panel A: Sample with optimism measure constructed from stockholdings and more constrained subsample firms

\begin{tabular}{|c|c|c|c|c|c|c|c|c|c|c|}
\hline & \multirow{2}{*}{\multicolumn{2}{|c|}{$\begin{array}{l}\text { Sample with optimism measure } \\
\text { constructed from stockholdings }\end{array}$}} & \multicolumn{8}{|c|}{ More constrained subsample firms } \\
\hline & & & $\begin{array}{l}\text { Dividend } \\
\text { payout }\end{array}$ & \multirow{2}{*}{$\begin{aligned} \begin{array}{l}\text { Interest } \\
\text { coverage }\end{array} & 1.81 * * *\end{aligned}$} & \multirow{2}{*}{$\begin{array}{l}\text { Size } \\
2.22 * * *\end{array}$} & \multirow{2}{*}{$\begin{aligned} \text { Age } \\
1.65\end{aligned}$} & $\begin{array}{l}\text { Group } \\
\text { affiliation }\end{array}$ & Industry & \multirow{2}{*}{$\begin{array}{cc}\begin{array}{c}\text { Ownership } \\
\text { concentration }\end{array} \\
* & 2.19^{* * *}\end{array}$} & \multirow{2}{*}{$\begin{array}{l}\text { Cash flow } \\
\text { right } \\
1.64\end{array}$} \\
\hline Intercept $(\times 100)$ & 1.67 & 0.43 & $2.17 * *$ & & & & $3.24 * * *$ & $1.80 * * *$ & & \\
\hline Cash flow & $0.24 * * *$ & $0.24 * * *$ & $0.29 * * *$ & $0.18 * * *$ & $0.24 * * *$ & $0.46 * * *$ & $0.21 * * *$ & $0.28 * * *$ & $* \quad 0.20 * * *$ & $0.32 * * *$ \\
\hline$Q(\times 100)$ & $5.05 * *$ & $4.44 * * *$ & $1.16^{* *}$ & $1.35 * * *$ & $1.56^{* * *}$ & 0.95 & $0.71 *$ & $1.37 * * *$ & $* \quad 1.36 * * *$ & $1.83 * * *$ \\
\hline Optimism measure $(\times 100)$ & & $-1.65^{* *}$ & $-3.16^{* * *}$ & -1.30 & -1.43 & -1.46 & $-3.70 * * *$ & $-2.32 * * *$ & $*-2.72 * * *$ & $-3.75 * * *$ \\
\hline Cash flow $\times Q$ & & $-0.09 * *$ & -0.02 & -0.02 & $-0.08 * *$ & $-0.07 * * *$ & -0.01 & $-0.04 * * *$ & $*-0.01 * * *$ & $-0.07 * * *$ \\
\hline Cash flow $\times$ optimism measure & & $0.28 * * *$ & $0.48 * * *$ & $0.16^{* * *}$ & 0.11 & $0.16^{* * *}$ & $0.42 * * *$ & $0.34 * * *$ & $* \quad 0.50 * * *$ & $0.19 * * *$ \\
\hline Adjusted $R^{2}$ & 0.13 & 0.15 & 0.25 & 0.15 & 0.06 & 0.26 & 0.16 & 0.16 & 0.22 & 0.14 \\
\hline Observations & 1746 & 1746 & 630 & 824 & 563 & 455 & 769 & 1525 & 764 & 537 \\
\hline \multicolumn{11}{|c|}{ Panel B: Less constrained subsample firms } \\
\hline & $\begin{array}{l}\text { Dividend } \\
\text { payout }\end{array}$ & Interest coverag & \multicolumn{2}{|l|}{ Size } & Age & \multicolumn{2}{|c|}{$\begin{array}{l}\text { Group } \\
\text { affiliation }\end{array}$} & Industry & $\begin{array}{l}\text { Ownership } \\
\text { concentration }\end{array}$ & $\begin{array}{l}\text { Cash flow } \\
\text { right }\end{array}$ \\
\hline Intercept $(\times 100)$ & $1.81 * * *$ & $3.53 * * *$ & \multicolumn{2}{|c|}{1.02} & $2.14 * * *$ & \multicolumn{2}{|c|}{$1.12 *$} & $2.56^{* *}$ & $2.31 * * *$ & $3.09 * * *$ \\
\hline Cash flow & $0.16^{* * *}$ & 0.12 & \multicolumn{2}{|c|}{$0.36 * * *$} & $0.13 * * *$ & \multicolumn{2}{|c|}{$0.24 * * *$} & 0.07 & $0.21 * * *$ & $0.17 *$ \\
\hline$Q(\times 100)$ & $1.35 * * *$ & -0.04 & \multicolumn{2}{|c|}{$1.52 * * *$} & $1.89 * * *$ & $2.03 * * *$ & \multicolumn{2}{|c|}{$1.68 * * *$} & $1.11 * * *$ & $1.05 * *$ \\
\hline Optimism measure $(\times 100)$ & -0.28 & $-4.57 * * *$ & \multicolumn{2}{|c|}{$-2.30 * * *$} & -0.58 & $-2.16^{* *}$ & \multicolumn{2}{|c|}{$-3.32 *$} & $-2.52 * * *$ & $-0.50 * * *$ \\
\hline Cash flow $\times Q$ & $-0.02 *$ & $0.09 * * *$ & \multicolumn{2}{|c|}{$-0.05^{* * *}$} & $-0.04 * *$ & $-0.06 * * *$ & \multicolumn{2}{|c|}{-0.03} & $-0.03 * * *$ & -0.01 \\
\hline Cash flow $\times$ optimism measure & -0.01 & $0.77 * * *$ & \multicolumn{2}{|c|}{0.09} & -0.01 & $0.35^{* * *}$ & & $65 * * *$ & $0.15 * *$ & 0.10 \\
\hline Adjusted $R^{2}$ & 0.10 & 0.26 & & .19 & 0.09 & 0.16 & 0. & & 0.10 & 0.05 \\
\hline Observations & 888 & 922 & 1183 & & 1291 & 977 & 221 & & 79 & 576 \\
\hline
\end{tabular}

The dependent variable is investment. The definitions of the variables refer to the Appendix. To avoid possible distortion caused by firm size discrepancy, we normalize the investment and the cash flow by total assets at the beginning of the fiscal year. The alternative hypothesis is that the coefficient on the interaction of cash flow and the optimism measure is positive. $* * *, *$, and $*$ denote significant levels at $1 \%, 5 \%$, and $10 \%$, respectively. 
may differ. The expense of using the time-varying measure is a smaller sample size, the number of observations with the time-varying optimism measure in the regressions declines from 2124 to 1042.

Table 8 reports the OLS regression coefficients under the time-varying optimism measure. As for the optimism measure-cash flow interaction coefficients, we still find that in panel A, most of the coefficients are significantly positive in full sample and more constrained subsample. Moreover, under most of eight classifications the coefficients of more constrained firms on the optimism measure-cash flow interaction term are larger than those of less constrained firms in panel B.

It is noteworthy that most of the cash flow coefficients are smaller than those in Table 4 and insignificant. For example, in column 2 of panel A, we see that the coefficient is 0.04 and insignificant; but in panel A of Table 4, the respective coefficient is 0.10 and significant at a $10 \%$ level. Since there are two differences between Tables 4 and 8: the definition of optimism and the sample size, we further distinguish the source by using the subsample in Table 8 and the optimism definition in Table 4. Similar with Table 8, most of the cash flow coefficients are smaller and insignificant. ${ }^{13}$ The result suggests that the source of the finding may be the subsample in Table 8. The definition of the time-varying optimism is using only the forecasts prior to the investment period, which implies that the CEOs' earlier investment decisions may lack of respective time-varying optimism measure and that the subsample in Table 8 are the CEOs' later investment decisions. ${ }^{14}$ The explanation in the result of Table 5 could be possibly applied here.

To further substantiate our use of earnings forecasts as a measure of optimism, we also measure optimism with the CEOs' stockholdings as in Malmendier and Tate (2005). CEOs are exposed to their firms' idiosyncratic risk. Their personal wealth, reputation, and employability are linked to their firm's performance. However, CEOs cannot hedge their risk by short-selling stocks of their company. Therefore, Malmendier and Tate argue that CEOs should minimize their holdings of company stock. CEOs who are optimistic about future outcomes will repeatedly increase their equity positions early in their tenure in order to benefit from expected future gains. Among the 507 CEOs who meet our selection criteria, there are 335 CEOs keeping their positions for at least 5 years. We use their stockholdings for their first 3 years in tenure to define optimism. After computing the CEOs' average yearly stockholdings for their first 3 years of tenure, we classify them as optimistic if their average yearly shareholdings increase for at least 2 of the 3 years.

Table 9 presents the OLS regression results for the tests on the hypothesis under the managerial optimism measure constructed from stockholdings. We observe that in panel A, as for the coefficients on the optimism measure-cash flow interaction term, the sample with optimism measure constructed from stockholdings is 0.28 ; the more constrained subsample range from 0.11 to 0.50 . Eight of the nine coefficients are

\footnotetext{
13 Besides the subsample in Table 8, we also run remain (in Table 4 but not in Table 8) subsample and find that the cash flow coefficients are larger than those of the subsample in Table 8. The results are not reported here.

14 The average year of the CEOs in their positions of the subsample in Table 8 is 5.57, and that of remain subsample is 1.89 .
} 
significant at a $1 \%$ level. Panel B presents the OLS regression results of less constrained subsample firms. We still observe that the coefficients of more constrained firms on the optimism measure-cash flow interaction term are larger than those of less constrained firms under six of eight classifications. In short, the predictions for optimistic managers' investment behaviors are empirically supported in Taiwanese companies, whether we measure optimism from the management earnings forecasts or from stockholdings.

\section{Conclusions}

Compared to other areas of behavioral finance, literature for the impact of managerial optimism on corporate decisions is relatively rare. This paper proposes a measure of managerial optimism from their earnings forecasts. The measure is helpful to test the theoretical predictions for the behaviors of optimistic managers. To avoid a misidentification due to other incentives, we carefully eliminate biased forecasts that may be contaminated by effects such as stock offerings, financial distress, and insider trading. Even removing these forecasts from the sample; we still find that $69 \%$ of the CEOs meeting our selection criteria are classified as optimistic. The results indicate that managerial optimism may be a possible reason for the upward bias in management forecasts in Taiwan.

We explore the extent to which managerial optimism provides a satisfactory explanation for the investment decisions of listed Taiwanese firms. Focusing on whether cash flow plays a relatively more important role in investment decisions for optimistic managers than for non-optimistic managers, we use several classifications to identify whether firm is more constrained, and then regress the investment on the cash flow, the optimism measure, and the interaction of optimism and the cash flow using the more constrained firms. We find that in Taiwanese companies, optimistic managers exhibit higher investment-cash flow sensitivity than do non-optimistic managers. We rule out the possibility that the result is driven by traditional agency and information asymmetry explanation. Compared to prior literature that agency or information asymmetry problems result in the investment-cash flow sensitivity, this paper makes a contribution by providing evidence of an alternative source from which corporate decisions are impacted. The evidence proposes that managerial optimism plays a role in their investment decisions.

\section{Acknowledgements}

We would like to thank the editor, Kalok Chan, and the anonymous referee of this journal for their helpful suggestions. We would also like to thank Edward Chow, Bing-Huei Lin, Sheng-Syan Chen, Yuanchan Chang, Konan Chan, Hung-Jen Wang, seminar participants at the National Taiwan University, Chengchi University, and the 2004 National Taiwan University International Conference for helpful comments. Chen acknowledges the financial support from the National Science Council (93-2416-H-002-037). 


\section{Appendix A. Variable definitions}

\begin{tabular}{|c|c|}
\hline Variable name & Definition \\
\hline \multicolumn{2}{|l|}{ 1. Measure of optimism } \\
\hline $\begin{array}{l}\text { Measure of optimism constructed } \\
\text { from management earnings forecasts }\end{array}$ & $\begin{array}{l}\text { Dummy variable equal to } 1 \text { for the CEOs if they } \\
\text { have at least two earnings forecasts and if the } \\
\text { number of upward-biased forecasts is more than } \\
\text { that of downward-biased forecasts in their forecasts }\end{array}$ \\
\hline Upward bias & Forecast error is positive \\
\hline Downward bias & Forecast error is negative \\
\hline Forecast error & $\begin{array}{l}\text { Management forecast for earnings before tax-actual } \\
\text { earnings before tax }\end{array}$ \\
\hline $\begin{array}{l}\text { Measure of optimism constructed from } \\
\text { stockholdings }\end{array}$ & $\begin{array}{l}\text { Dummy variable equal to } 1 \text { for the CEOs if they keep } \\
\text { their position as CEO for at least } 5 \text { years and if their } \\
\text { average dividend-adjusted shareholdings increase for } \\
\text { at least two of the first } 3 \text { years in tenure }\end{array}$ \\
\hline Dividend-adjusted shareholdings & Shares adjusted for earning reserve and capital reserve \\
\hline \multicolumn{2}{|l|}{ 2. Test for optimism and investment } \\
\hline Investment & -(Purchase) fix assets-sale fix assets \\
\hline Cash flow & $\begin{array}{l}\text { Earnings before interest, taxes, depreciation, and } \\
\text { amortization (EBITDA) }\end{array}$ \\
\hline Q & $\operatorname{Ln}[1+($ Market value of equity/book value of equity) $]$ \\
\hline Market value of equity & Market capitalization \\
\hline Book value of equity & $\begin{array}{l}\text { Total assets - total liabilities }+ \text { miscellaneous long-term } \\
\text { liabilities - preferred stocks }\end{array}$ \\
\hline Lagged assets & Total assets at the beginning of the fiscal year \\
\hline \multicolumn{2}{|l|}{ 3. Classifications for more constrained firms } \\
\hline Dividend payout & $\begin{array}{l}\text { The ratio of the number of years with non-zero cash } \\
\text { dividend to that in the sample period }\end{array}$ \\
\hline Interest coverage & $\begin{array}{l}\text { The ratio of interest expense to the sum of the } \\
\text { interest expense and the cash flow }\end{array}$ \\
\hline Firm size & Total assets \\
\hline Age & The number of years the firm had been listed \\
\hline Business group affiliation & $\begin{array}{l}\text { Whether a firm is in a business group (from the } \\
\text { business Groups in Taiwan, 1990-2002) }\end{array}$ \\
\hline Industry & SFC sector \\
\hline Ownership concentration & Directors and supervisors' shareholdings rate $(\%)$ \\
\hline Cash flow right of the controlling shareholder & $\begin{array}{l}\text { The average cash flow rights of the ultimate } \\
\text { controlling shareholders }\end{array}$ \\
\hline
\end{tabular}

\section{References}

Agung, J., 2000. Financial constraints, firms' investments and the channels of monetary policy in Indonesia. Applied Economics 32, 1637-1646.

Alicke, M., Klotz, M., Breitenbecher, D., Yurak, T., et al., 1995. Personal contact individuation, and the betterthan-average effect. Journal of Personality and Social Psychology 68 (5), 804-825.

Ami, E., Ganzach, Y., 1998. Overreaction and underreaction in analysts' forecasts. Journal of Economic Behavior and Organization 37 (3), 333-347. 
Betker, B., Ferris, S., Lawles, R., 1999. Warm With Sunny Skies: Disclosure Statement Forecasts, Working Paper. University of Missouri-Columbia, Columbia MO.

Calomiris, C., Hubbard, R., 1995. Internal finance and firm-level investment: evidence from the undistributed profits tax of 1936-1937. Journal of Business 68 (4), 443-482.

Chevalier, J., Ellison, G., 1999. Career concerns of mutual fund managers. Quarterly Journal of Economics 114, $389-431$.

Chin, C., Lin, H., Chang, Y., 1999. Mandatory management forecast errors as a variable to earnings manipulation, with a $20 \%$ hurdle set by TAIEX regulators. Journal of Financial Studies 7 (1), 59-96.

Cleary, S., 1999. The relationship between firm investment and financial status. Journal of Finance 54 (2), 673-692.

Core, J., 2001. A review of the empirical disclosure literature: discussion. Journal of Accounting and Economics $31,441-456$

DeAngelo, H., DeAndelo, L., Skinner, D., 1996. Reversal of fortune dividend signaling and the disappearance of sustained earnings growth. Journal of Financial Economics 40, 341-371.

Fazzari, S., Hubbard, R., Peterson, B., 1988. Financing constraints and corporate investment. Brookings Paper on Economic Activity 1, 141-195.

Frost, C., 1997. Disclosure policy choices of UK firms receiving modified audit reports. Journal of Accounting and Economics 23, 163-187.

Gervais, S., Heaton, J., Odean, T., 2002. The Positive Role of Overconfidence and Optimism in Investment Policy. Working Paper. University of California, Berkeley.

Gilson, S., 1989. Management turnover and financial distress. Journal of Financial Economics 25, $241-262$.

Hackbarth, D., 2002. Managerial Optimism, Overconfidence, and Capital Structure Decisions. Working Paper. University of California, Berkeley.

Heaton, J., 2002. Managerial optimism and corporate finance. Financial Management 31, $33-45$.

Holmstrom, B., 1982. Managerial Incentive Problems-A Dynamic Perspective, Essays in Economics and Management in Honor of Lars Wahlbeck (Helsinki: Swedish School of Economics).

Hoshi, T., Kashyap, A., Scharfstein, D., 1991. Corporate structure liquidity and investment: evidence from Japanese panel data. Quarterly Journal of Economics 106, 33-60.

Hu, X., Schiantarelli, F., 1998. Investment and capital market imperfections: a switching regression approach using U.S. firm panel data. Review of Economics and Statistic 80 (3), 466-479.

Hubbard, R., 1998. Capital-market imperfections and investment. Journal of Economic Literature 36, $193-225$.

Hubbard, R., Kashyap, A., Whited, T., 1995. Internal finance and firm investment. Journal of Money, Credit and Banking 27, 683-701.

Irani, A., 2003. Management earnings forecast bias and insider trading: comparison of distressed and nondistressed firms. Journal of Business and Economics 9 (1), 12-25.

Jelic, R., Saadouni, B., Briston, R., 1998. The accuracy of earnings forecasts in IPO prospectuses on the Kuala Lumpur Stock Exchange. Accounting and Business Research 29, 57-72.

Jensen, M., 1986. Agency costs of free cash flow, corporate finance and takeovers. American Economic Review $76,323-329$.

Koch, A., 1999. Financial Distress and the Credibility of Management Earnings Forecasts. Working Paper. Carnegie Mellon University Press, Pittsburgh, PA.

Kothari, S., Shanken, J., Sloan, R., 1995. Another look at the cross-section of expected stock returns. Journal of Finance 50, 185-224.

Lang, M., Lundholm, R., 2000. Voluntary disclosure during equity offerings: reducing information asymmetry of hyping the stock?. Contemporary Accounting Research 17, 623-662.

La Porta, Lopez-de-Silanes, Shleifer, A., 1999. Corporate ownership around the world. Journal of Finance 54, $471-517$.

Larwood, L., Whittaker, W., 1977. Managerial myopia: self-serving biases in organizational planning. Journal of Applied Psychology 62, 194-198.

March, J., Sharpia, Z., 1987. Managerial perspectives on risk and risk taking. Management Science 33, 1404-1418.

Marquardt, C., Weidman, C., 1998. Voluntary disclosure, information asymmetry, and insider selling through secondary equity offerings. Contemporary Accounting Research 15, 505-538. 
Melmendier, U., Tate, G., 2005. CEO overconfidence and corporate investment. Forthcoming in Journal of Finance.

Myers, S., Majluf, N., 1984. Corporate financing and investment decisions when firms have information that investors do not have. Journal of Financial Economics 13, 187-221.

Noe, C., 1999. Voluntary disclosures and insider transactions. Journal of Accounting and Economics 27, $305-327$.

Ritter, J., 2003. Behavioral finance. Pacific-Basin Finance Journal 11, 429-437.

Roll, R., 1986. The hubris hypothesis of corporate takeovers. Journal of Business 59 (2), $197-216$ (part 1).

Schaller, H., 1993. Asymmetric information, liquidity constraints and Canadian investment. The Canadian Journal of Economics 26 (3), 552-574.

Shen, C., Wang, C., 2000. Whether financing constraint affects investment decisions: evidence from Taiwan panel data. Academia Economic Papers 28 (1), 67-95.

The Business Groups in Taiwan, 1990-2002. China Credit Information Service, Ltd.

Tobin, J., 1969. A general equilibrium approach to monetary theory. Journal of Money, Credit, Banking 1 (1), $15-29$.

Weinstein, N., 1980. Unrealistic optimism about future life events. Journal of Personality and Social Psychology $39,806-820$.

Whited, T., 1992. Debt, liquidity constraints and corporate investment: evidence from panel data. Journal of Finance $47,1425-1460$. 